\title{
Resistance of alkali-activated slag to sulphate attack and elevated temperatures
}

\author{
Aya allah M. Ebrahim ${ }^{3}$, Essam A. Kishar ${ }^{1}$, Doaa A. Ahmed ${ }^{2}$ \\ ${ }^{1}$ Professor of inorganic chemistry, ${ }^{2}$ Assistant prof. of inorganic chemistry, ${ }^{3}$ Assistant lecture \\ of inorganic and analytical chemistry \\ Chemistry Dep., Faculty of Girls, Ain Shams University, Cairo, Egypt.
}

\begin{abstract}
Thermal stability as well as sulphate resistance of alkali activated slag (AAS) pastes prepared from Ground Granulated Blast Furnace Slag (GGBFS) and 5\% fly ash (FA) are examined. AAS pastes are accelerated using alkaline solution of sodium hydroxide with concentration 1, 1.5 and $2 \mathrm{M}$ and sodium silicate with fixed concentration $(0.28 \mathrm{~mol} / \mathrm{Kg})$. AAS pastes exposed to $5 \% \mathrm{MgSO}_{4}$ solution and to high temperature (200, 400, 600 and 800 $\left.{ }^{\circ} \mathrm{C}\right)$. The compressive strength, bulk density, total porosity, chemically combined water content and phase composition are determined in this study. Concentration of $2 \mathrm{M} \mathrm{NaOH}$ with $5 \%$ FA promotes the best properties of AAS pastes that exhibit the highest resistance to firing up to $400^{\circ} \mathrm{C}$ by achieving the greatest compressive strength. However, AAS pastes activated by $2 \mathrm{M} \mathrm{NaOH}$ give a high sulphate resistance.
\end{abstract}

Keywords: Alkali activated slag, Fly ash, Geopolymer materials, Sulphate and fire resistance.

\section{Introduction}

A significant amount of Portland cement is used in construction around the world. However, the production of OPC contributing between 5 and $7 \%$ of the current anthropogenic $\mathrm{CO}_{2}$ emissions worldwide that production of 1 ton of OPC producing up to 1 tone of $\mathrm{CO}_{2}$. It is also energy extensive process. Therefore, the quest for alternatives to usage of supplementary cementitious materials has got a great momentum to protect the environment. One potential alternative binder material is alkali activated materials or geopolymer which is materials characterized by chains or networks of inorganic molecules. It is produced by the alkali activation of aluminosilicate raw materials by polymerization in presence of high $\mathrm{pH}$ environment. The polymerization reaction involves the formation of three dimensional polymeric chains by $\mathrm{Si}-\mathrm{Al}$ minerals to form a ring structure which consist of Si-O-Si bonds (Rajerajeswan et al., 2013).

Geopolymer materials exhibit engineering properties compared to OPC, such as compressive strength and higher resistance to chemical attack, freezing and high temperatures (wardhono et al., 2017).

Corresponding author: Email: Ayaallah.mahmoud@yahoo.com 
Hence in order to reducing the impact of unwanted materials and to produce more environmentally friendly materials is to partially replace OPC with by product materials as granulated blast furnace slag (GBFS). GBFS is aluminosilicate raw material that can be activated by alkali hydroxide and silicate. Alkali activation of slag leads to a reaction product similar to calcium silicate hydrates (CSH) gel but with aluminium in its composition which is calcium aluminium silicate hydrate (CASH) gel.

Several studies (Kumar et al., 2010; Puertas et al., 2000 ; Rashad, 2013) revealed that the creation of extra calcium due to the inclusion of GBFS into FA geopolymer is responsible for the improvement of the mechanical and microstructure properties of the system. Qureshi and Ghosh (2014) were observed an increase in compressive strength with increasing in alkali content til $10.41 \%$. Further increase in alkali content reduces the compressive strength.

The mechanical properties and microstructure of alkali activated slag subjected to temperatures at $400{ }^{\circ} \mathrm{C}, 600{ }^{\circ} \mathrm{C}$ and $800{ }^{\circ} \mathrm{C}$ for 1 hour and 2 hours duration have been reported (Li et al., 2016). He reported that the strength decreased by $23.9 \%$ to $35 \%$ at elevated temperature of $400{ }^{\circ} \mathrm{C}$. A remarkable drop in strength was observed after exposure to $800{ }^{\circ} \mathrm{C}$, and decreased by $87.0 \%$ in comparison with the reference specimens.

Heikel et al. (2014) state that the activated GBFS showed good durability in 5\% $\mathrm{MgSO}_{4}$ or $5 \% \mathrm{MgCl}_{2}$ solution, i.e., the compressive strength increased gradually with immersing time up to 180 days.

Fly ash (FA) is a by-product of the combustion of coal in thermal power Plants with spherical, ranging in diameter from $<1 \mu \mathrm{m}$ up to $150 \mu \mathrm{m}$. Slag blended FA geopolymer revealed good resistance against permeation, elevated temperature and fire as well as sodium sulphate ( $\mathbf{L i}$ and liu, 2007 ; Guerrieri and Sanjayan, 2010). However, it displayed declination against magnesium sulphate attack with enhanced shrinkage (Ismail et al., 2013). Huseien et al. (2016) emphasized that mortars containing 20\% FA revealed higher performance under elevated temperature compared to mortars with low FA content.

Kurklu (2016) prepared geopolymer mortars by replacing blast furnace slag with fly ash in different proportions $(0,25,50$ and $75 \%)$ and subjected to temperatures of 200 , $400,600,800$ and $1000^{\circ} \mathrm{C}$. According to the results, 400 and $600^{\circ} \mathrm{C}$ were considered as critical temperature for changes in mechanical and physical properties. However, the geopolymer mortars lost around $58 \%$ of its strength at $1000^{\circ} \mathrm{C}$.

\section{Materials and methods}

\subsection{Materials}

Materials used in this investigation were: granulated blast furnace slag (GBFS) obtained from the Egyptian iron \& steel of Helwan Company with Blaine surface area $4700 \pm 50 \mathrm{~cm}^{2} / \mathrm{g}$. Fly ash (FA) is provided from Sika Egypt Company, Obour, Egypt with surface area 300 to $500 \mathrm{~m}^{2} / \mathrm{Kg}$. Sodium silicate liquid (SSL) is provided from Silica Egypt Company, Burg Al-Arab, Alexandria, Egypt and Sodium hydroxide (SH) pellets is provided from El Nasr Pharmaceutical Chemicals Company, Qalyubiya, Egypt. The chemical analyses of the utilized materials are given in Table (1). 
Table (1): Chemical composition of starting materials

\begin{tabular}{|c|c|c|c|c|c|c|c|c|c|c|c|c|}
\hline \multirow[b]{2}{*}{$\begin{array}{c}\text { Material } \\
\mathbf{s}\end{array}$} & \multicolumn{9}{|c|}{ Oxide (\%) } & \multirow[b]{2}{*}{$\begin{array}{c}\text { L.O. } \\
\text { I }\end{array}$} & \multirow[b]{2}{*}{$\begin{array}{c}\mathrm{H}_{2} \\
\mathbf{O}\end{array}$} & \multirow[b]{2}{*}{ Total } \\
\hline & $\mathrm{SiO}_{2}$ & $\begin{array}{c}\mathrm{Al}_{2} \mathrm{O} \\
3\end{array}$ & $\begin{array}{c}\mathrm{Fe}_{2} \mathrm{O} \\
3\end{array}$ & $\mathrm{CaO}$ & $\begin{array}{c}\mathrm{Mg} \\
\mathbf{O}\end{array}$ & $\mathrm{SO}_{3}$ & $\begin{array}{c}\mathbf{K}_{2} \\
\mathbf{O}\end{array}$ & $\begin{array}{c}\mathrm{Na}_{2} \\
\mathbf{O}\end{array}$ & $\mathrm{Cl}^{-}$ & & & \\
\hline Slag & $\begin{array}{c}34.1 \\
\text { 0 }\end{array}$ & 12.40 & 0.77 & $\begin{array}{c}42.3 \\
0\end{array}$ & 6.50 & $\begin{array}{c}0.9 \\
0\end{array}$ & 0.35 & 0.26 & $\begin{array}{c}0.0 \\
8\end{array}$ & 1.50 & -- & 99.60 \\
\hline FA & $\begin{array}{c}63.2 \\
0\end{array}$ & 26.34 & 5.10 & 2.20 & 0.10 & $\begin{array}{c}0.1 \\
5\end{array}$ & 0.76 & 0.44 & -- & 2.30 & -- & $\begin{array}{c}100.5 \\
9\end{array}$ \\
\hline SSL & $\begin{array}{c}32.8 \\
\text { 0 }\end{array}$ & -- & -- & -- & -- & -- & -- & $\begin{array}{c}11.7 \\
\text { 0 }\end{array}$ & -- & -- & 55.5 & 100 \\
\hline
\end{tabular}

\subsection{Experimental technique}

\subsubsection{Alkaline activator}

The alkali activator (AA) was prepared by mixing sodium silicate solution and sodium hydroxide pellets with mechanically stirring. The temperature of the mixture is initially high so it left till reach to room temperature in few minutes before proceeding.

\subsubsection{Preparation of mixes}

The mix compositions of the prepared samples are shown in Table (2). The paste specimens are prepared by adding the prepared activator to dry mixes and mixed for 3 min. The pastes are then cast into $25 \times 25 \times 25 \mathrm{~mm}$ molds. The mold is vibrated for 1 minute to ensure no air/voids are present in the specimens. Finally, the molds were held at a nearly $95 \%$ relative humidity for preventing drying and giving enough time (24 hrs) to the pastes to set and harden at ambient temperature, i.e. $25{ }^{\circ} \mathrm{C}$. The specimens are cured using two different curing regimes, 1) cured under tap water until the required hydration time 1, 3, 7, 28, 90, and 180 days of curing, 2) After 28 days curing under tap water (Zero time), the specimens are then immersed in $5 \% \mathrm{MgSO}_{4}$ up to 180 days. The $\mathrm{MgSO}_{4}$ solution is renewed monthly.

For the specimens which are tested for firing effect, all specimens (at 28 days curing time) are exposed, in an electric furnace to four target temperatures, $200^{\circ} \mathrm{C}, 400$ ${ }^{\circ} \mathrm{C}, 600{ }^{\circ} \mathrm{C}$ and $800{ }^{\circ} \mathrm{C}$, with a heating rate of $10{ }^{\circ} \mathrm{C} / \mathrm{min}$ from room temperature. Once the target temperature was attained, it was maintained for 1 hour. Afterwards, the specimens were cooled to room temperature.

\subsection{Methods of investigation}

The physico-chemical and mechanical characteristics of geopolymer mixes are tested via:

1. Compressive strength tests are performed on three cubes of each paste using a Ton industric machine (Germany) for maximum load of $55 \mathrm{KN}$. The mean value of the obtained results is considered and is recorded in $\mathrm{Kg} / \mathrm{cm}^{2}$. 
2. Total porosity and bulk density tests are carried out by determining the weight of the samples of the hardened pastes suspended in water, $\mathrm{W}_{2}$, and those in air, $\mathrm{W}_{1}$ then dried at $100^{\circ} \mathrm{C}$ for about 24 hours and weighed in air, $\mathrm{W}_{3}$. The total porosity is calculated using the following equation:

$$
\text { Total Porosity } \%=\left[\left(\mathrm{W}_{1}-\mathrm{W}_{3}\right) /\left(\mathrm{W}_{1}-\mathrm{W}_{2}\right)\right] \times 100
$$

While, the bulk density is calculated using the following equation:

$$
\text { Bulk density }=\left[\mathrm{W}_{3} /\left(\mathrm{W}_{1}-\mathrm{W}_{2}\right)\right]
$$

3. The chemically combined water content (Wn) is calculated from the relation,

$$
\mathrm{Wn} \%=\left[\left(\mathrm{W}_{1}-\mathrm{W}_{2}\right) /\left(\mathrm{W}_{2}\right)\right] \times 100
$$

Where; $\mathrm{W}_{1}$ : weight of the sample before ignition and $\mathrm{W}_{2}$ : weight of the sample after ignition at $900^{\circ} \mathrm{C}$.

4. The phase compositions of the formed hydrates are investigated by means of a Philips X-ray diffractometry (PW 1390) using $\mathrm{Cu}-\mathrm{K} \alpha$ and Ni filter under working conditions of 40 kilo volts, 25 milliampers and $2^{\circ} \mathrm{C} / \mathrm{min}$.

Table (2): Mixes composition and designations

\begin{tabular}{|c|c|c|c|c|c|}
\hline Mix abb. & $\begin{array}{c}\text { GBFS, } \\
\text { Wt. \% }\end{array}$ & $\begin{array}{c}\text { FA, } \\
\text { Wt. \% }\end{array}$ & $\begin{array}{c}\text { SH } \\
\text { Conc.(M) }\end{array}$ & $\begin{array}{c}\text { SSL } \\
\text { Conc. } \\
\text { (mol/Kg) }\end{array}$ & $\begin{array}{c}\text { W/S } \\
\text { Ratio \% }\end{array}$ \\
\hline S1 & 100 & 0 & 1.0 & 0.28 & 30 \\
\hline S2 & 100 & 0 & 1.5 & 0.28 & 30 \\
\hline S3 & 100 & 0 & 2.0 & 0.28 & 30 \\
\hline SF1 & 95 & 5 & 1.0 & 0.28 & 32 \\
\hline SF2 & 95 & 5 & 1.5 & 0.28 & 32 \\
\hline SF3 & 95 & 5 & 2.0 & 0.28 & 32 \\
\hline
\end{tabular}

\section{Results and Dissections}

\subsection{Sulphate resistance of slag geopolymer}

\subsubsection{Compressive strength}

The compressive strength values of mixes containing $100 \%$ slag activated by 1 , 1.5 and $2 \mathrm{M}$ sodium hydroxide are represented graphically in Fig. (1). It is found that the compressive strength increases with hydration time up to 180 days. This is due to the higher rate of hydration as well as formation of more hydration products. It is also observed that the compressive strength values are increased with increasing in alkali concentration. Similar finding reported by (Allahverdi et al. 2008; Wang et al. 2014). A stronger alkali promotes greater degree of hydration in the slag because the ability of $\mathrm{OH}^{-}$ions to attack the slag structure. The $\mathrm{OH}^{-}$ions create intermediary reactants which lastly precipitate into $\mathrm{CSH}$ and other final products. Moreover, anions in 
sodium silicate react with $\mathrm{Ca}^{+2}$ dissolving from the surface of slag grains to form C-S-H so it accelerates the activation process.

Alkali activated slag (100\% slag) at different activated concentration is sulphate-resistant, because unlike the Portland cement, AAS does not rely on lime and not dissolved by sulphate solutions. In addition, calcium hydroxide is consumed by the progressive pozzolanic reaction of GGBFS (Khater, 2013).

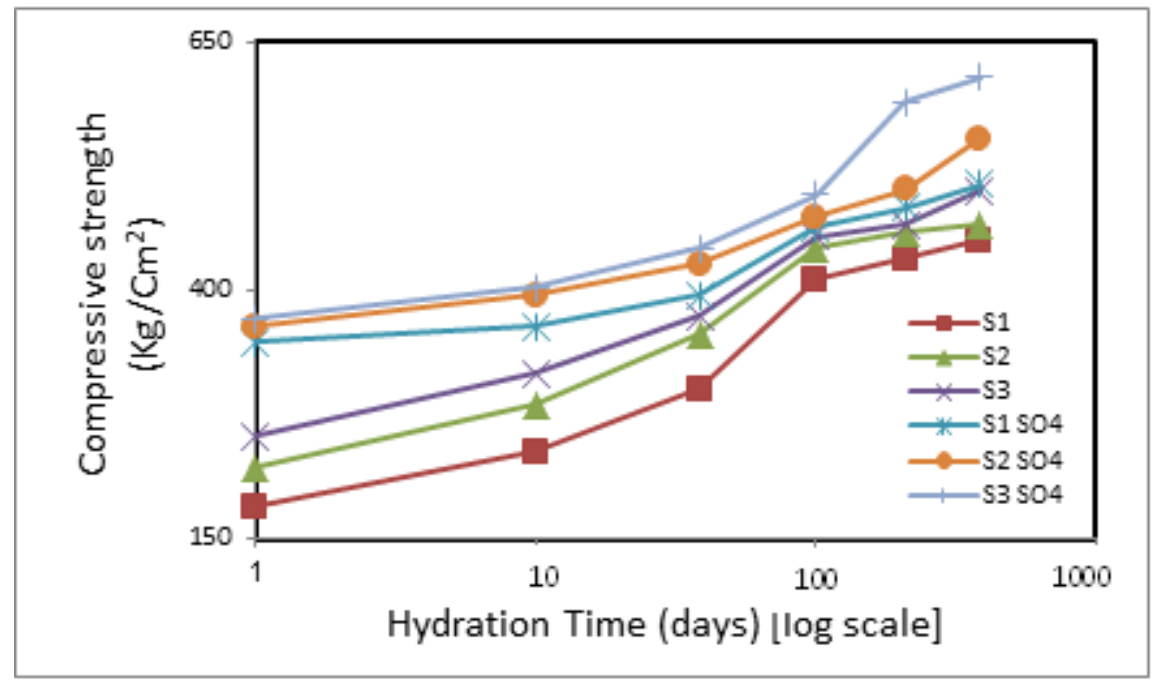

Figure (1): Compressive strength of mixes containing 100\% slag.

Fig. (2) shows the changes in the compressive strength of geopolymer mixes at different hydration ages on adding $5 \%$ FA with different alkaline activator $(1,1.5$ and $2 \mathrm{M}$ ). It can be noticed that the compressive strength increases with hydration time up to180 days for all mixes. It can be also shown that the values of compressive strength are increased by increasing alkali concentration up to $2 \mathrm{M}$ with $5 \% \mathrm{FA}$. This influence is due to the higher solubility of alumino-silicates compounds in concentrated alkaline solutions which enhance the geopolymerization process. In other hand, the addition of FA may lead to a higher content of fine particles within the paste, which could work as micro aggregates and reduce the total porosity, then result in an increment of strength. The AAS mixes showed good stability on its compressive strength values in $5 \% \mathrm{MgSO}_{4}$ solution. However, specimens containing FA exhibit lower resistance to sulphate attack than those of $100 \%$ GBFS. This is due to the chemical composition of fly ash containing $\left(26.34 \% \mathrm{Al}_{2} \mathrm{O}_{3}\right)$ which leads to formation of delayed non-uniform heterogeneously ettringite localized expansion in hardened pastes undergoes loss of its mechanical properties. 


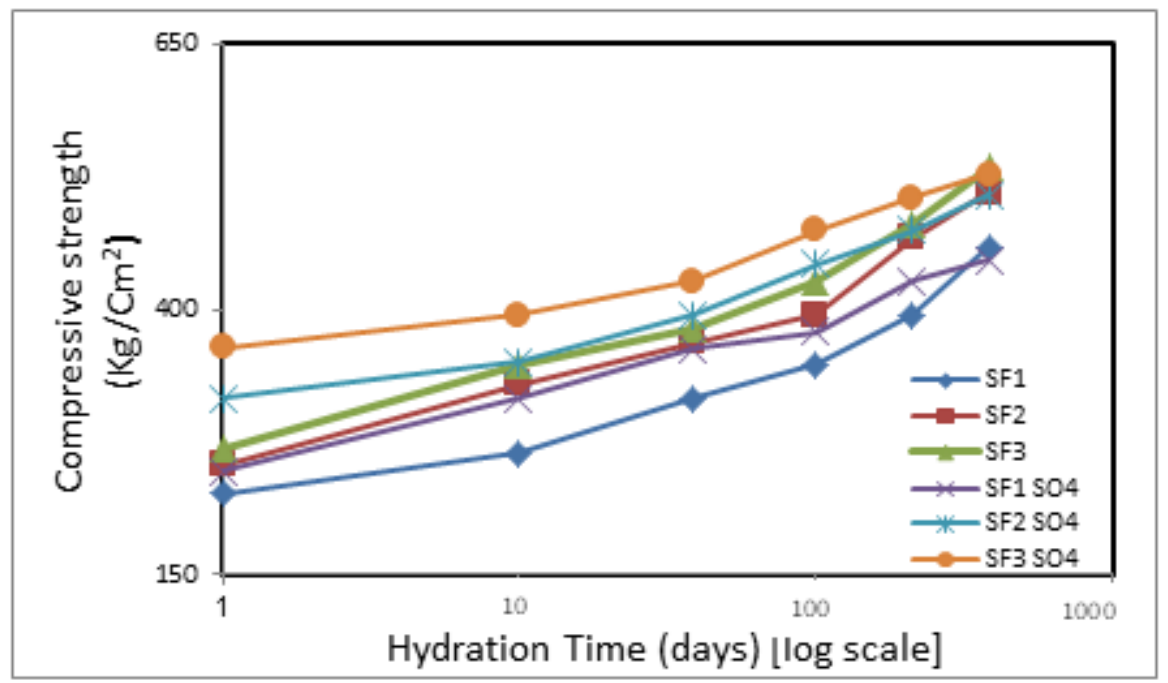

Figure (2): Compressive strength of mixes containing 5\% FA.

\subsubsection{Bulk Density}

The bulk density of AAS cured up to 180 days are presented in

Figs. $(3 \&$ 4). It is clear that the bulk density increases with curing time up to 180 days and with alkaline activator up to $2 \mathrm{M}$. This increase is due to the continuous activation and formation of hydration products that makes more homogeneous and denser microstructure results in increase the bulk density. Increasing alkaline activator concentration enhance the production of higher concentration of $\left[\mathrm{SiO}_{4}\right]^{-4}$ which form more $\mathrm{CSH}$ and $\mathrm{CASH}$.

The bulk density values are in a good agreement with compressive strength values, such that as the bulk density increase the compressive strength also increase.

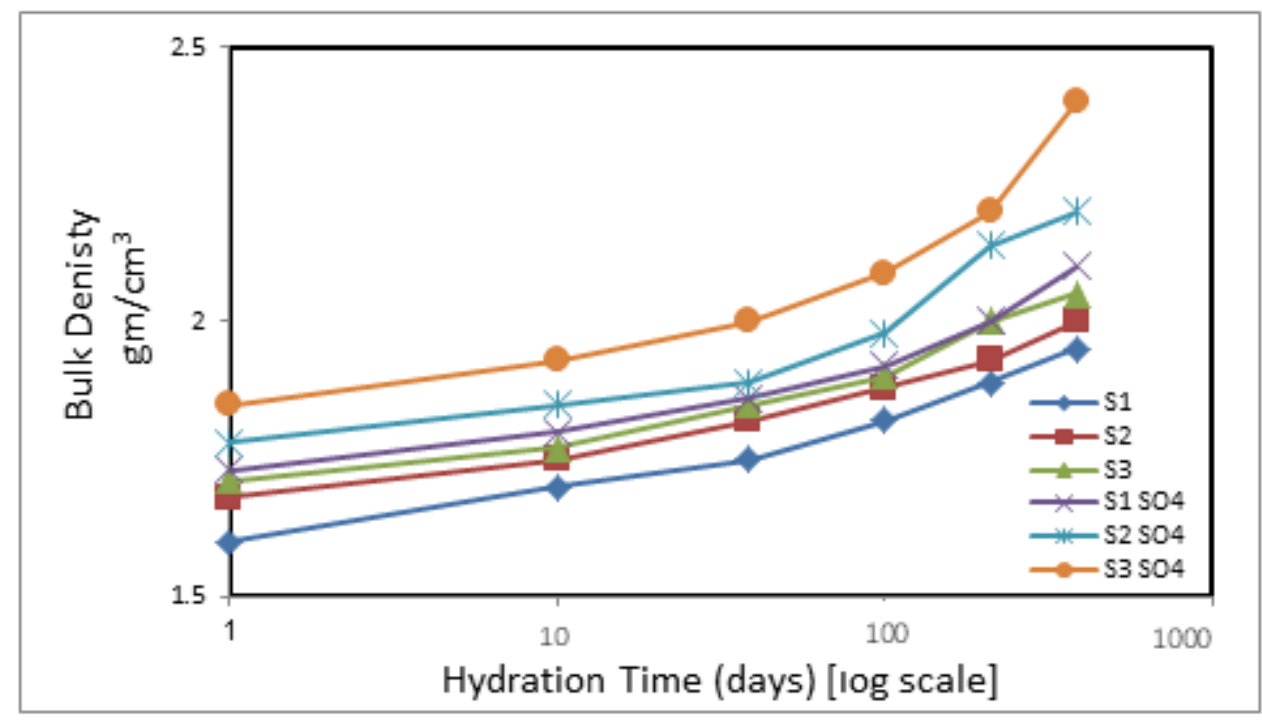

Figure (3): Bulk density of mixes containing $100 \%$ slag. 


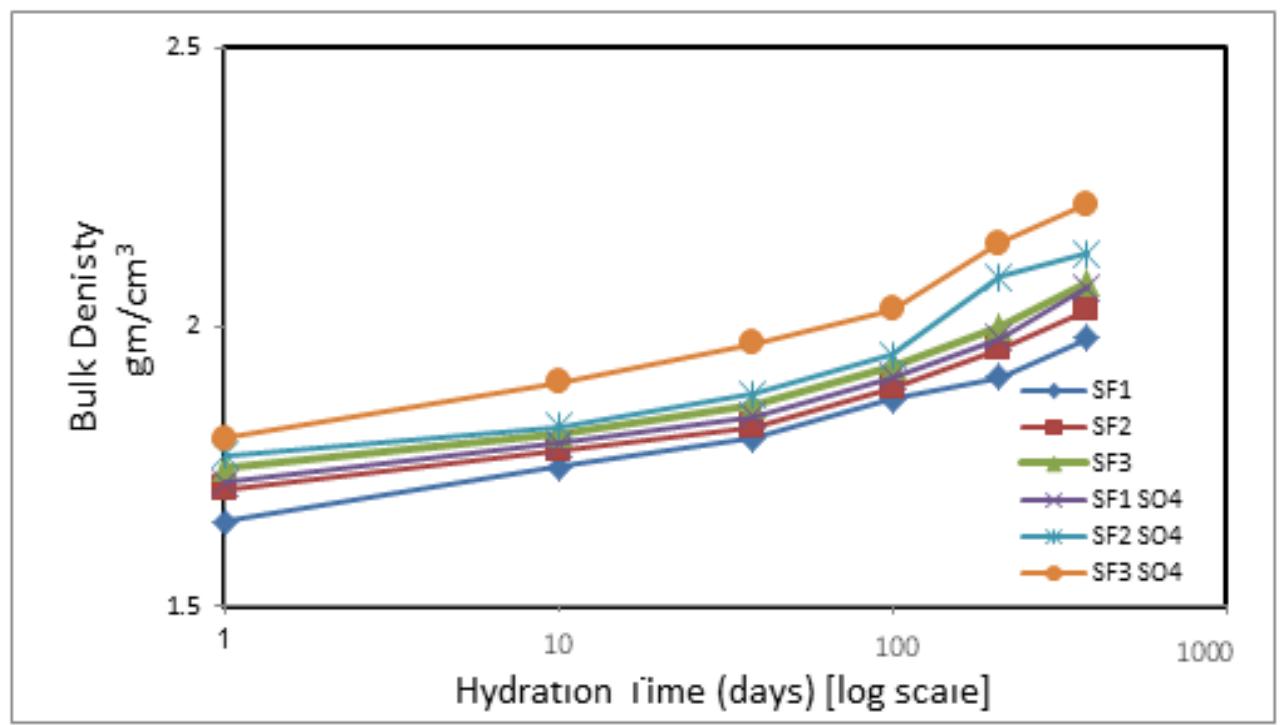

Figure (4): Bulk density of mixes containing 5\% FA.

\subsubsection{The total porosity (P \%):}

The total porosities of AAS as well as AAS blended with FA at different hydration ages are represented graphically in Figs. $(5 \& 6)$ respectively. According to total porosity values, $\mathrm{P} \%$ decreases as the alkaline activator of GBFS increases. In presence of $5 \% \mathrm{FA}$, the total porosities decrease. This is fundamentally due to the increase of the alkaline activator concentration; more hydration products are formed by accelerating the activation process of GBFS. These hydration products fill a part of the available voids of the pastes leading to decrease the total porosity. Such results agree with those of the compressive strength.

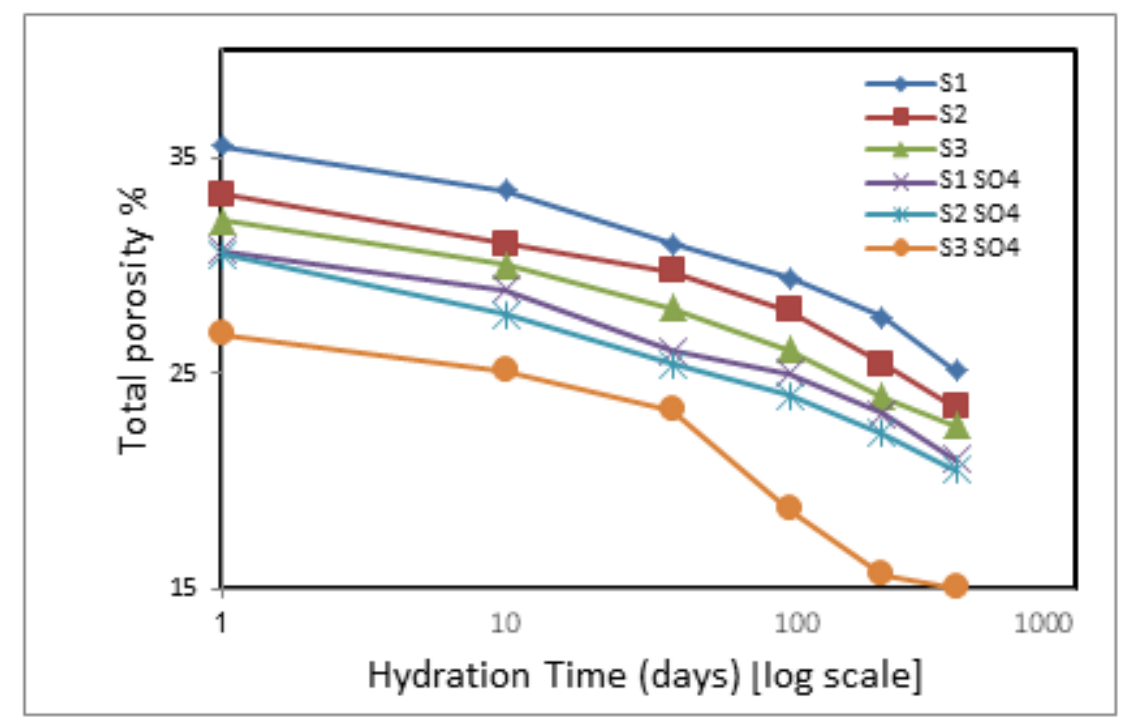

Figure (5): Total porosity of mixes containing $100 \%$ slag. 


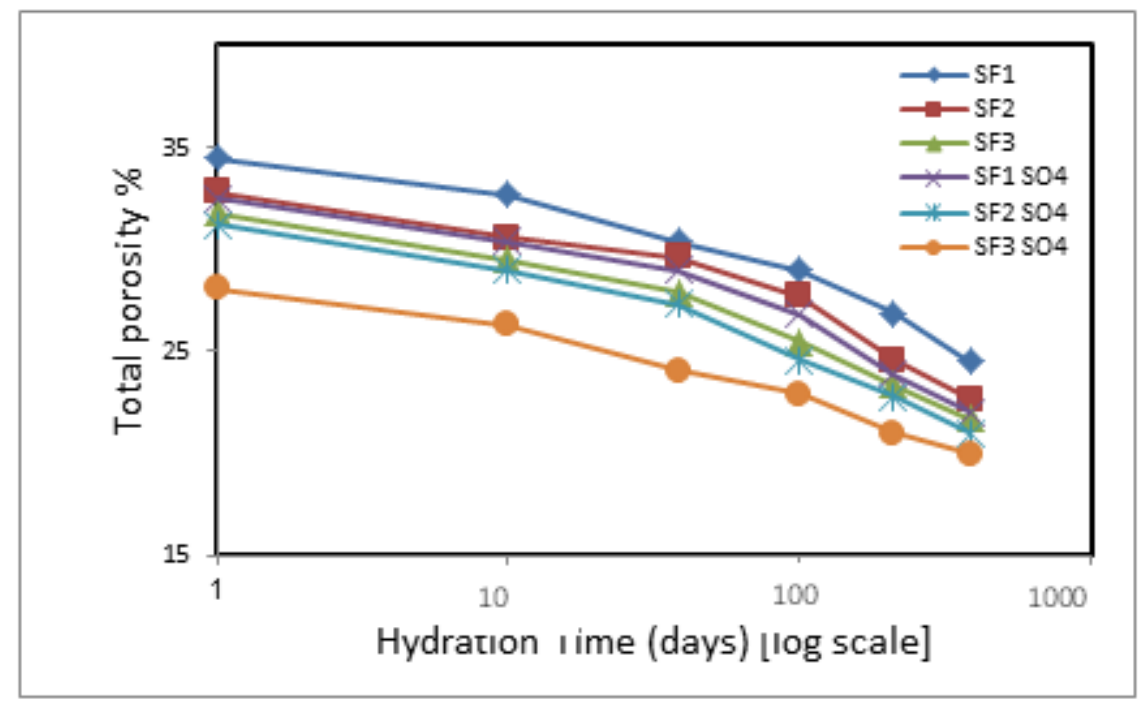

Figure (6): Total porosity of mixes containing 5\% FA.

\subsubsection{The chemically combined water:}

The obtained results of chemically combined water contents of mixes of $100 \%$ GBFS are represented in Fig. (7). All mixes are found to show a continuous increase in the chemically combined water content with increasing hydration time up to 180 days. This may be attributed to the progress of the hydration of geopolymer constituents to form the corresponding hydration products that accumulate in available open pores. The $\mathrm{W}_{\mathrm{n}}$ contents of AAS increase with alkali content up to $2 \mathrm{M}$. Increase the concentration of alkaline activator may enhance the hydration of AAS by increasing the rate of dissolution of the GBFS.

The $\mathrm{W}_{\mathrm{n}}$ contents of specimens containing 5\% FA are given in Fig. (8). The results indicate that $\mathrm{W}_{\mathrm{n}}$ content increases linearly with curing time up to 180 days. It is also found that $\mathrm{W}_{\mathrm{n}}$ content is increased with adding FA. This is due to high pozzolanic reactivity of FA results in the formation of additional $\mathrm{C}-\mathrm{S}-\mathrm{H}$ during the interaction between FA, as active silica, with free lime released accounts for higher strength values of the hardened pastes.

In the aggressive solution $\left(5 \% \mathrm{MgSO}_{4}\right)$ also the combined water contents of the alkali activated GBFS pastes gradually increases up to 180 days in all mixes. The same result obtained by addition of FA due to the continuous hydration and accumulation of hydration products. 


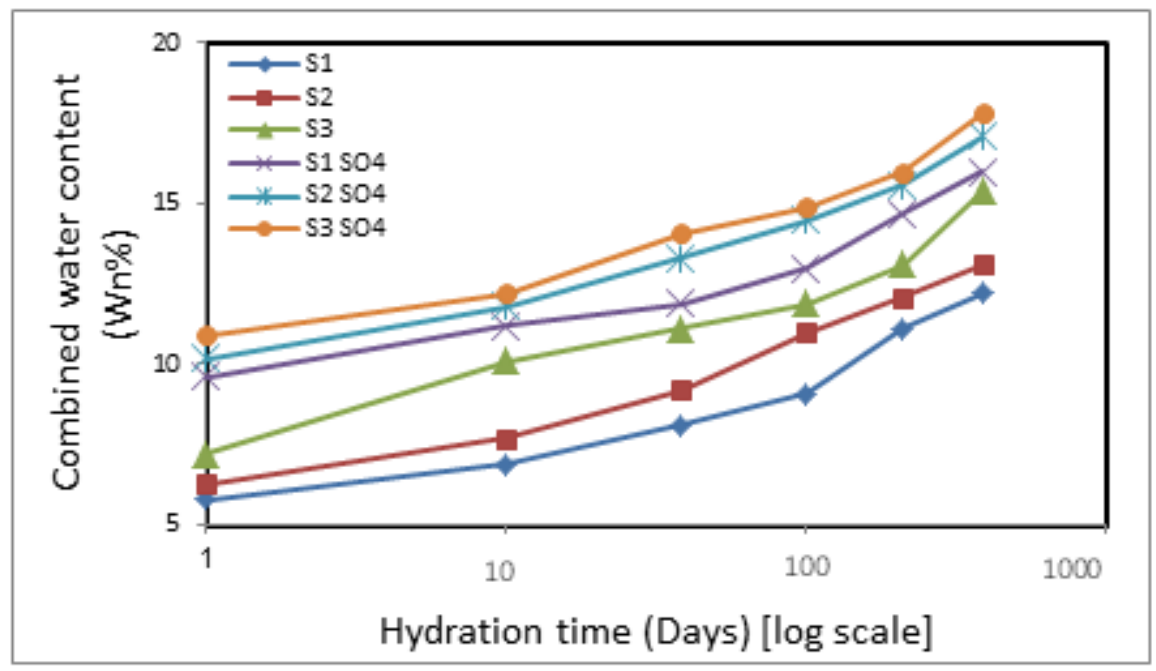

Figure (7): Chemically combined water content of mixes containing $100 \%$ slag.

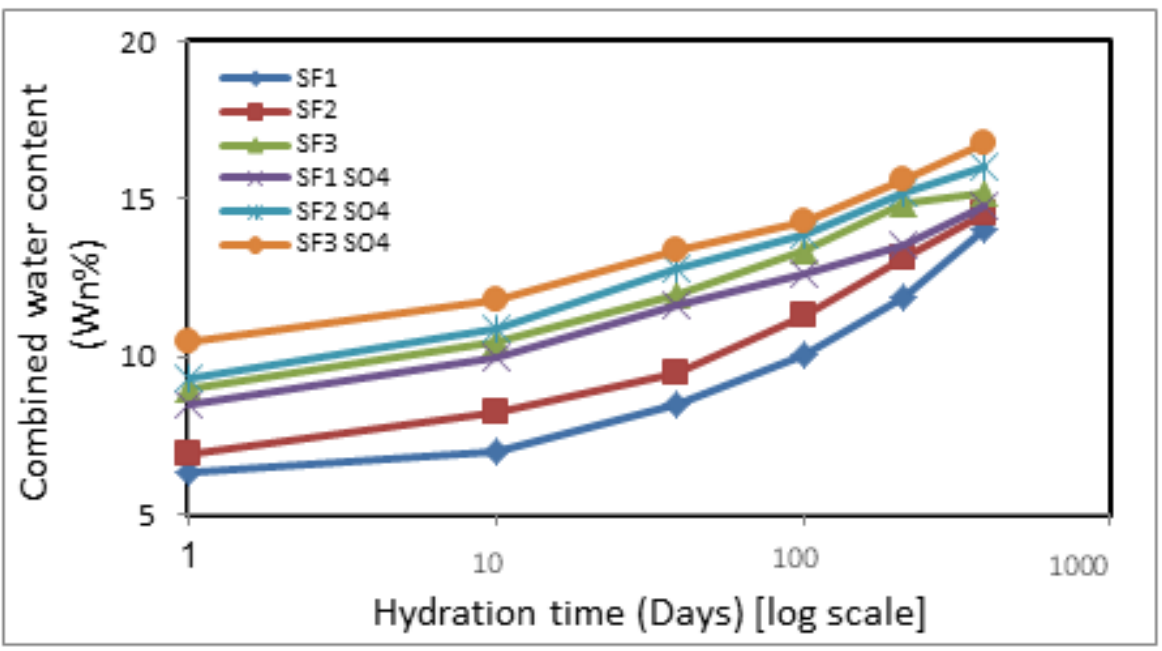

Figure (8): Chemically combined water content of mixes containing 5\% FA.

\subsection{Fire resistance of geopolymer}

\subsubsection{The compressive strength}

The compressive strength values of alkali activated GBFS mix specimens and that contain 5\% FA, fired at different temperatures 200, 400, 600 and $800{ }^{\circ} \mathrm{C}$ are plotted graphically in Figs. (9). An important increase in compressive strength for S1, S2 and S3 mixes (about 8, 12 and $15 \%$ respectively) is observed when exposed to $200^{\circ} \mathrm{C}$. This is most likely due to heating accelerates the hydration process of activated slag particles which increased the compressive strength remarkably. Similar finding are reported by (Turker et al., 2016). Similar behavior is also found at $400^{\circ} \mathrm{C}$, where the compressive strength of all AAS mixes is increased by values up to $45 \%$ for $\mathrm{S} 3$ mix. Increasing firing temperature up to 600 and $800^{\circ} \mathrm{C}$ leads to decrease in compressive strength up to $64 \%$. This explained by low matrix cohesion up on high temperature which resulted from dehydroxylation of geopolymer network that leads to weakness of its mechanical properties. Alkali activated slag paste by $2 \mathrm{M}$ $\mathrm{NaOH}$ (S3) exhibits higher compressive strength at all elevated temperature compared to the other mixes. This is because of the formation of improved alumina-silicate networks during 
geopolymerisation process such as nepheline $\left[\mathrm{NaAlSiO}_{4}\right]$, gehlenite $\left[\mathrm{Ca}_{2} \mathrm{Al}\left(\mathrm{AlSiO}_{7}\right)\right]$, Analcime $\left[\mathrm{Na}\left(\mathrm{AlSi}_{2} \mathrm{O}_{6}\right) \cdot \mathrm{H}_{2} \mathrm{O}\right]$ and Quartz as shown later in XRD pattern.

Addition of FA leads to the formation of geopolymer structure that can withstand at high temperature up to $400^{\circ} \mathrm{C}$ and possess a thermal stability higher than that of comparable GBFS mixes. This thermal stability can be related to the better rearrangement of geopolymer structure by partial replacement by FA that results in the formation of a compact matrix. Moreover, a steep decrease in compressive strength is perceived up to $800^{\circ} \mathrm{C}$ which may be attributed to development of large pores that possibly connected to material decomposition upon heating. This accompanied by the increase of average pore size as the amorphous structures were replaced by the crystalline Na-feldspars that will possess a pessimism effect on the matrix stability and hence its mechanical characteristics.

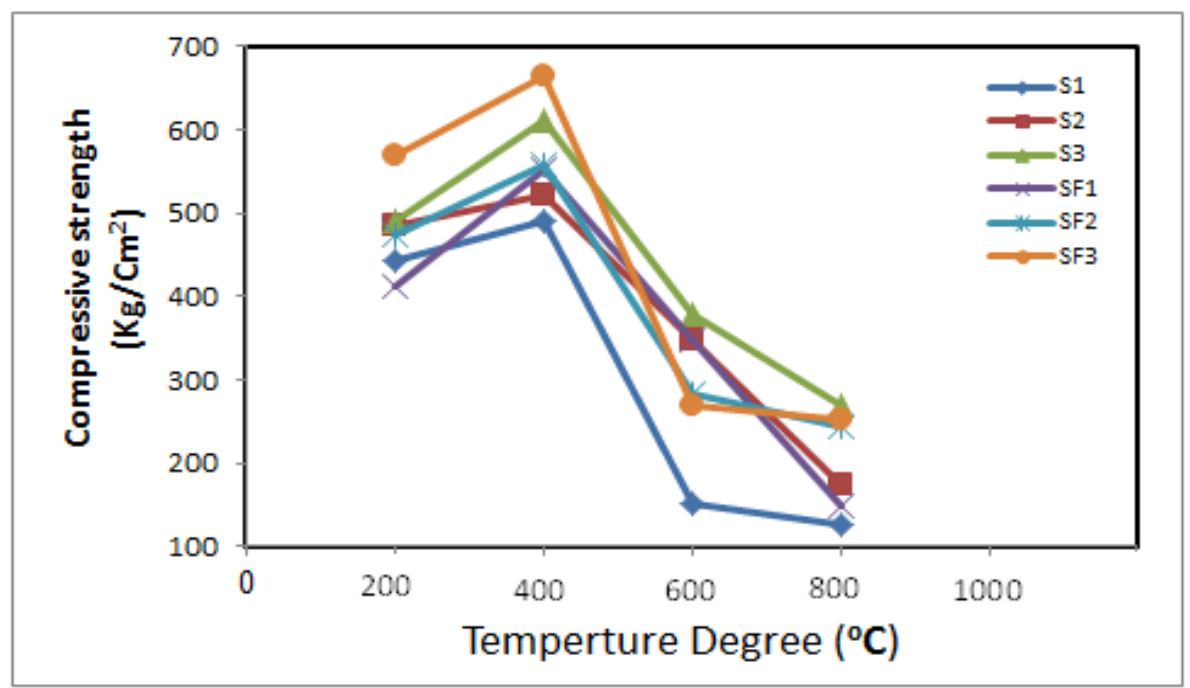

Figure (9): The compressive strength values of all mixes at various firing temperature.

\subsubsection{The XRD analysis}

Figs. (10 \& 11) show the XRD analysis of the hardened AAS and FA pastes exposed to elevated temperature; $200,400,600$, and $800^{\circ} \mathrm{C}$, respectively for one hour. XRD technique might be used to acquire a better understanding of the possible transformations wherefore exposed to high temperature in alkali activated slag. The XRD confirmed the compressive strength values that all mixes resist the high temperature up to $400^{\circ} \mathrm{C}$ followed by sharp decrease at 600 and $800^{\circ} \mathrm{C}$.

The XRD patterns of all mixes at 200 and $400^{\circ} \mathrm{C}$ show an amorphous CSH phase which responsible for the compressive strength. In addition, the broad band in region $2 \Theta=25$ $35^{\circ}$ suggests that the main reaction product formed is low crystalline alkaline aluminosilicate gel. Increasing the compressive strength values can be attributed to activation of polymerization reaction by formation of improved alumina-silicate networks during geopolymerisation process in pastes containing high molar $\mathrm{NaOH}$ concentration exhibited higher compressive strength at all elevated temperatures (Shaikh and Vimonsatit, 2015).

At 600 and $800^{\circ} \mathrm{C}$, the XRD results indicated that an obvious crystal transformation formed when the specimens subjected especially to $800{ }^{\circ} \mathrm{C}$ thermal treatment for 1 hour duration. The crystalline phase of anhydrous calcium silicate such as Gehlenite $(\mathrm{d}=2.84,1.92$, 1.81, $\left.1.76 \mathrm{~A}^{\mathrm{o}}\right)$, Nepheline $\left(\mathrm{d}=3.86,3.23,2.97,2.8 \mathrm{~A}^{\mathrm{o}}\right)$, Analcime $\left(\mathrm{d}=5.53,3.42 \mathrm{~A}^{\mathrm{o}}\right)$ and 
Quartz $\left(\mathrm{d}=3.34 \mathrm{~A}^{\circ}\right)$ are found in the XRD pattern, and the diffraction peaks of C-S-H gels were disappeared. According to Ye et al., (2014) all of the above crystalline phases for the AAS pastes are alumino-silicate minerals balanced by alkali metal ions such as $\mathrm{Na}^{+}$and $\mathrm{Ca}^{2+}$.

A sharp decrease in compressive strength at 600 and $800^{\circ} \mathrm{C}$ can be attributed to the decomposition of the $\mathrm{CSH}$ and $\mathrm{CASH}$ phases, which are the binding agent in hardened pastes, to crystalline phases by evaporating water.

Furthermore, as the concentration of $\mathrm{NaOH}$ increased, the intensity of these crystalline phases increased. This is due to while the alkali activator concentration increase, sodium ion increase in solution that balanced more alumina-silicate network leading to formation of more crystalline phases.
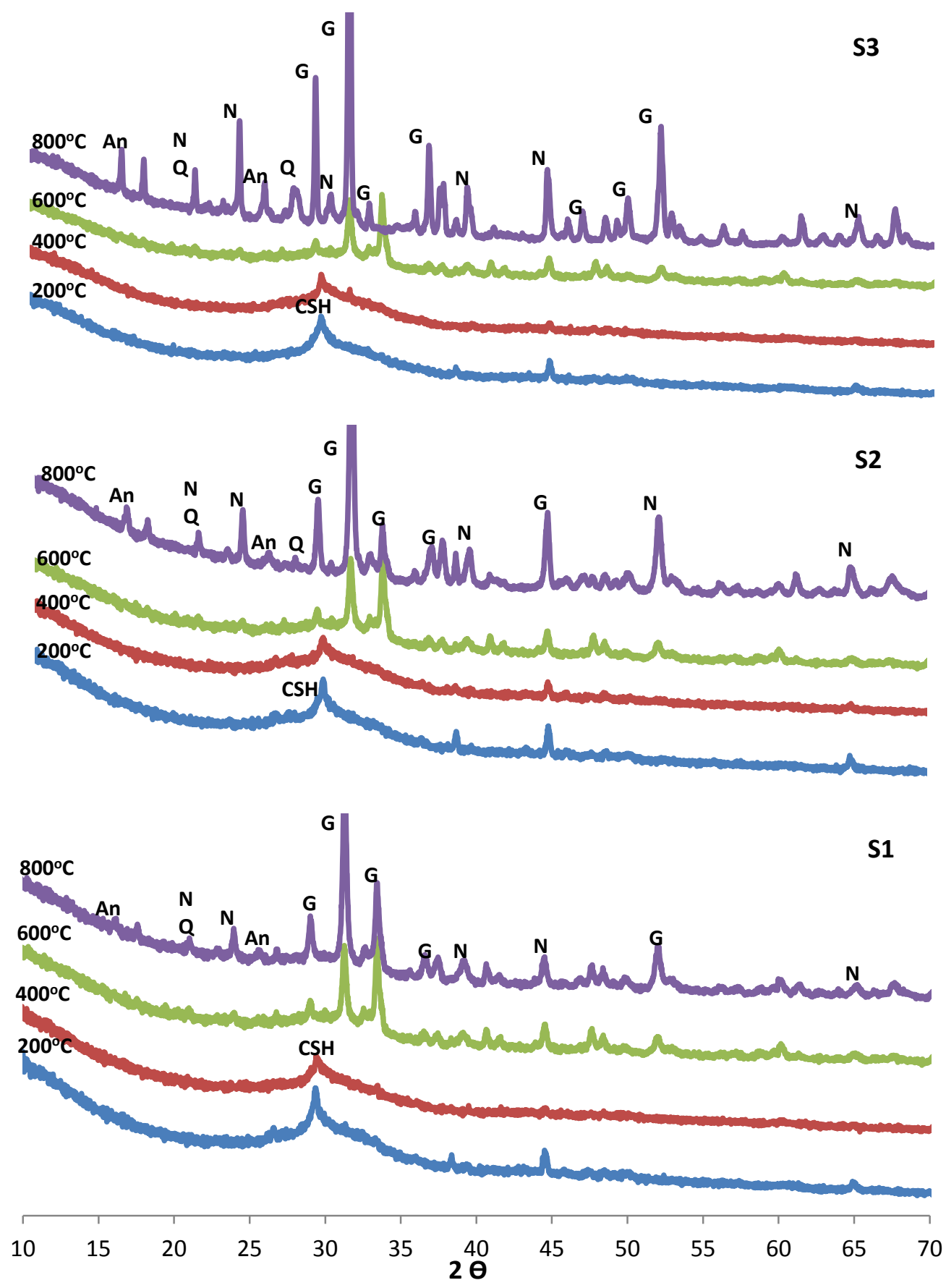

Figure (10): XRD of S1, S2 and S3 fired at different temperatures. 
An= Analcime; $\mathrm{N}=$ Nepheline $; \mathrm{G}=$ Gehlenite; $\mathrm{Q}=$ Quartz

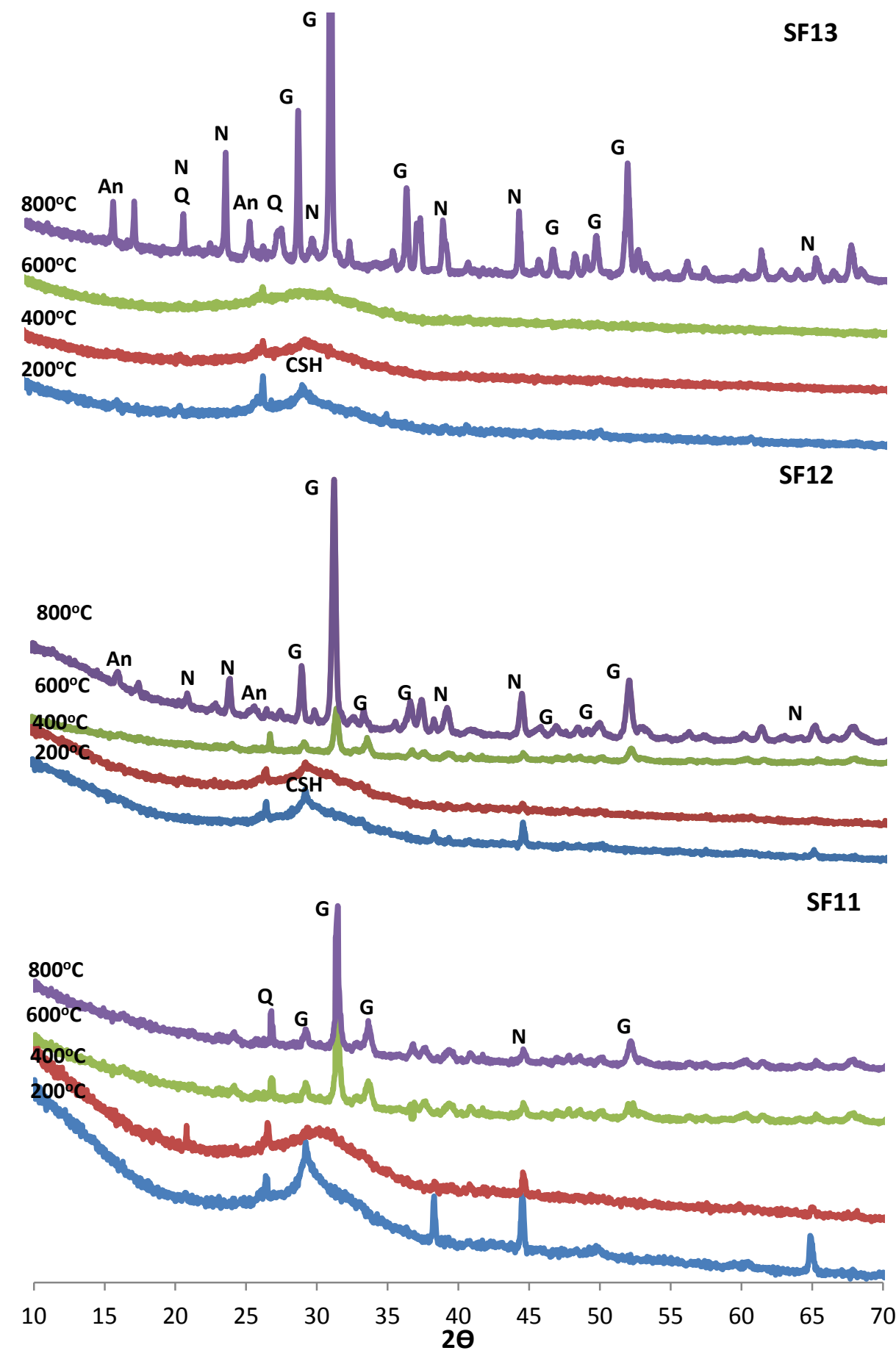

Figure (11): XRD of SF11, SF12 and SF13 fired at different temperatures. $\mathrm{An}=$ Analcime; $\mathrm{N}=$ Nepheline $\mathrm{G}=$ Gehlenite; $\mathrm{Q}=\mathrm{Quartz}$ 


\section{Conclusion}

The effects of different molarities of $\mathrm{NaOH}$ solutions, sulphate attack and different temperature exposure on the compressive strength of slag based geopolymer pastes are evaluated in this paper.

On the basis of the experimental study of the compressive strength of alkali activated slag pastes, the following conclusions can be drawn:

- AAS pastes blended with 5\% FA show higher compressive strength values than AAS pastes under curing in tap water. However, AAS pastes exhibit the highest sulphate resistance.

- The bulk density and total porosity values are a good agreement with compressive strength values that as the compressive strength increase, the bulk density increases and total porosity decreases.

- The firing effect, all pastes show an increase in compressive strength up to $400^{\circ} \mathrm{C}$ and sharply decrease up to $800^{\circ} \mathrm{C}$.

- The increase in compressive strength is attributed to acceleration of hydration process AAS pastes by heating. While, the reduce in compressive strength is due to dehydroxylation of geopolymer network that leads to weakness of its mechanical properties.

- $\mathrm{S} 3$ is exhibits the highest sulphate resistance however, SF3 give the highest compressive strength value up to $400^{\circ} \mathrm{C}$.

\section{Reference}

Allahverdi A., Mehrpour K., and Kani E.N., "Pozzolan-Based Geopolymer Cement". International Journal of Engineering Science. 19(3) (2008) 1-5.

Wardhono A., Chamila Gunasekara, David W. Law and Sujeeva Setunge "Comparison of long term performance between alkali activated slag and fly ash geopolymer concretes". Construction and Building Materials 143 (2017) 272-279.

Huseien G.F., Jahangir Mirza, Mohmmed Ismail and Mohd Warid Hussin "Influence of different curing temperatures and alkali activators on properties of GBFS geopolymer mortars containing fly ash and palm-oil fuel ash". Construction and Building Materials 125 (2016) 1229-1240.

Kurklu G., "The effect of high temperature on the design of blast furnace slag and coarse fly ash-based geopolymer mortar". Composites part B: Engineering 92 (2016) 918.

Guerrieri M. and Sanjayan J.G., "Behavior of combined fly ash/slag-based geopolymers when exposed to high temperatures". Fire Materials 34 (4) (2010) 163175.

Turker H.T., Muzeyyen Balcikanli, Ibrahim Halil Durmus, Erdogan ozbay and Mustafa Erdemir "Microstructural alteration of alkali activated slag mortars depend on exposed high temperature level”. Construction and Building Materials 104 (2016) 169-180. 
Ismail I., Bernal S.A., Provis J.L., Hamdan S. and van Deventer J.S., "Microstructural changes in alkali activated fly ash/slag geopolymers with sulfate exposure". Materials Structure 46 (3) (2013) 361-373.

Khater HM "Effect of Silica Fume on the Characterization of the Geopolymer Materials". International journal of advanced structural engineering 5(1) (2013) 5-12.

Kumar S., Kumar R. and Mehrotra S.P., "Influence of granulated blast furnace slag onthe reaction, structure and properties of fly ash based geopolymer". Journals of Materials Science 45 (3) (2010) 607-615.

Li Z. and Liu S., "Influence of slag as additive on compressive strength of fly ash based geopolymer. Journal of Mechanical and Civil Engineering 19 (6) (2007) 470-474.

Heikal M., Nassar M.Y., El-Sayed G., Ibrahim S.M., "Physico-chemical, mechanical, microstructure and durability characteristics of alkali activated Egyptian slag". Construction and Building Materials 69 (2014) 60-72.

Qureshi M. and Ghosh S., "Alkali-Activated Blast furnace Slag as a Green Construction Material". In proceeding of the International Conference on Advances in Engineering \& Technology, India, (2014) 24-28.

Puertas F., Martınez-Ramırez S., Alonso S. and Vazquez T., "Alkali-activated fly ash/slag cements: strength behaviour and hydration products". Cement and Concrete Researches 30(10) (2000)1625-1632.

Rajerajeswan A., Dhinakaran G. and Mohamed Ershad, "Compressive strength of silica fume based geopoylmer concrete". Asian Journal of Applied science 7 (2013) 240-247.

Rashad A.M. "Properties of alkali-activated fly ash concrete blended with slag". Iranian Journals of Materials Science and Engineering 10 (1) (2013) 57-64.

Shaikh F.U.A. and Vimonsatit V., "Compressive strength of fly ash-based geopolymer concrete at elevated temperatures". Fire and materials 39 (2015) 174-188.

Li T., Zhang Y. and Dai J., "Properties of Alkali Activated Slag Mortar after Exposure to Elevated Temperatures for Different Time". Proceedings of the World Congress on Civil, Structural, and Environmental Engineering (CSEE'16) 102(2016)1-7.

Wang W., Wang H. and lo M., "The engineering properties of alkali-activated slag pastes exposed to high temperature". Construction and Building Materials 68 (2014) 409-415.

Ye J., Zhang W., and Shi D., "Effect of elevated temperature on the properties of geopolymer synthesized from calcined ore-dressing tailing of bauxite and groundgranulated blast furnace slag". Construction and Building Materails 69 (2014) 41-48. 


\section{الملخص باللغة العربيه}

\section{مقاومة الخبث المنشط قلويا لأملاح الكبريتات و درجات الحرارة المرتفعة \\ عصام عبد العزيز كيشار، دعاء عبد المنعم، اية الله محمود ابراهيم* \\ قسم الكيمباء - كلية البنات ـ جامعة عين شمس}

تعتبر صناعة الاسمنت من اكثر الصناعات الملوثة للبيئة و ذلك لانبعاث ثانى اكسيد الكربون و

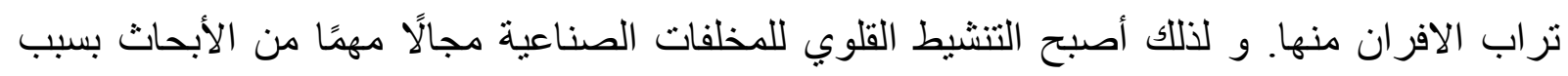

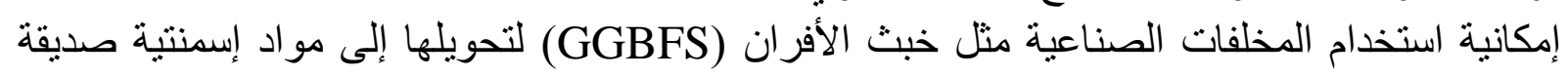
للبيئة وغير مكلفة وذات فائدة تكنولوجية.

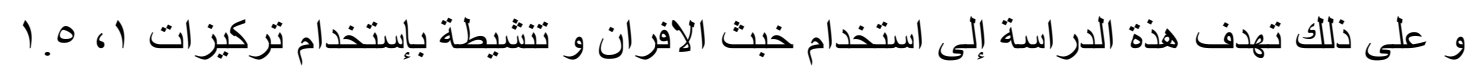

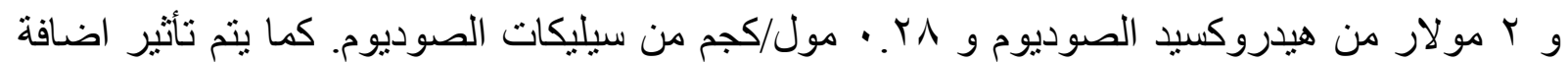

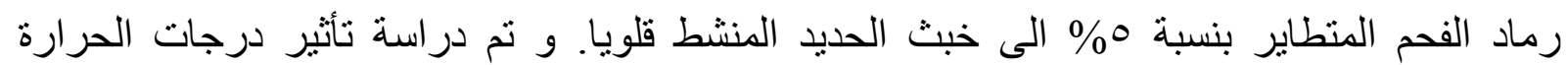

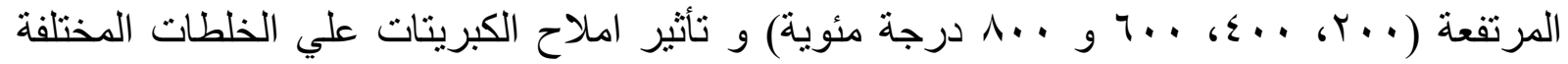

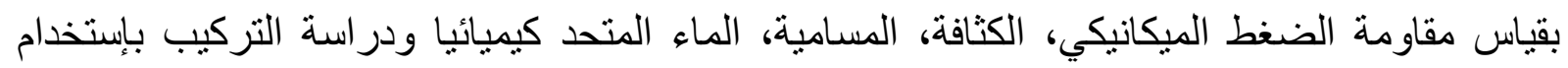
حيود الاشعة السينية .

\section{ويمكن تلخيص اهم النتائج التي حصلنا عليها فيما يلي:}

أظهرت جميع المخاليط مقاومة ضغط ميكانيكي جيد حتي ـ1 ا يوم وذلك بسبب المحتوي القلوي

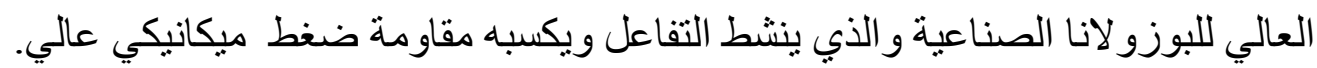

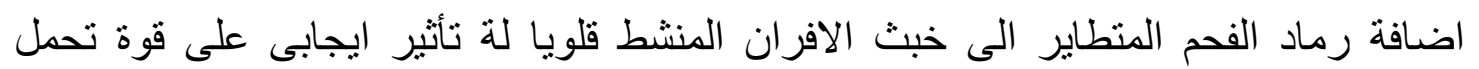

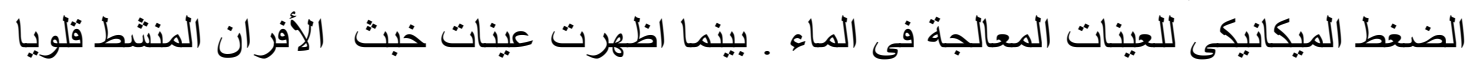

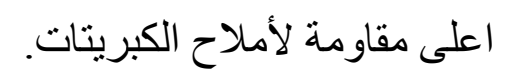
اعطى خليط خبث الأفران المنشط بإستخدام r مولار من هيدروكسبد الصوديوم اعلى مقاومة لأملاح الكبريتات.

كلماز ادت قوة تحمل العينات للضغط الميكانيكى كلماز ادت الكثافة و انخفضت المسامية الكلية.

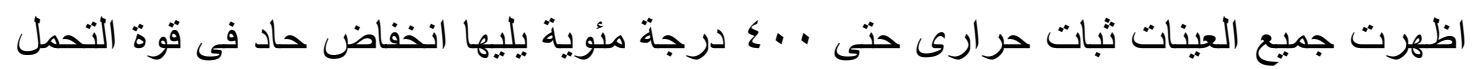

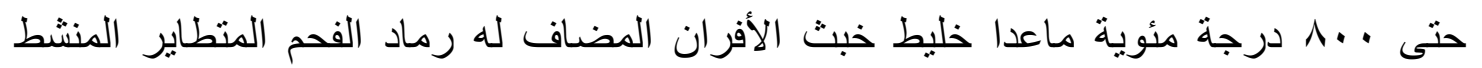

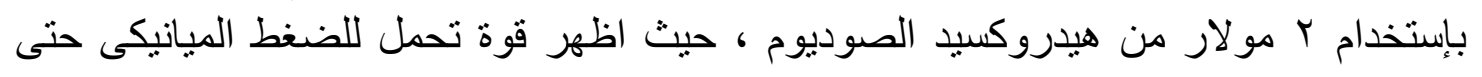

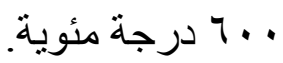

يرجع زيادة قوة تحمل العينات للضغط الميكانيكى حتى ل . ع درجة مئوية الى تنشيط عملية

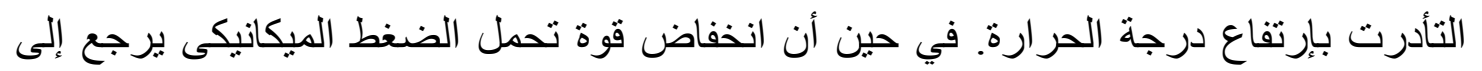
إز الة الهيدروكلوكسي من شبكة الجيوبوليمر التي تؤدي إلى ضعف فئ خصائصسه الميكانيكية. 